\title{
Seth Jacobs, America's Miracle Man in Vietnam. Ngo Dinh Diem, Religion, Race, and U.S. Intervention in Southeast Asia, Durham, N.C. Duke University Press 2004, ss. 381.
}

Książka Setha Jacobsa America's Miracle Man in Vietnam. Ngo Dinh Diem, Religion, Race, and U.S. Intervention in Southeast Asia ${ }^{1}$ liczy 381 stron rzetelnej analizy, opatrzonej starannymi przypisami oraz imponującą bibliografią. We wstępie - podzielonej na 6 rozdziałów pracy - autor zwraca uwagę na fakt, iż publikacje odnoszące się do amerykańskiego zaangażowania w Wietnamie zwykle wychodzą spod pióra historyków dyplomacji, a nie badaczy ideologii, co stanowi poważny mankament literatury przedmiotu. Cytując Richarda Slotkina, Jacobs postuluje badanie „tworzenia symboli, interpretacji i projekcji twórczej, które ciągle zazębiają się z politycznymi i materialnymi procesami społecznymi” (s. 21).

Tom America's Miracle Man in Vietnam jawi się właśnie jako próba przedstawienia decyzji dotyczących amerykańskiego zaangażowania w Wietnamie podejmowanych przez administrację Dwighta D. Eisenhowera w latach 1954-1957, próba uwzględniająca również tło ideologiczne Ameryki lat pięćdziesiątych $\mathrm{XX}$ wieku. Autor sięga nie tylko do dokumentów, ale również publikacji prasowych, literatury czy filmów fabularnych. Tak bogate spektrum źródeł służyć ma zrekonstruowaniu kompletnego obrazu pogłębiającego się zaangażowania Stanów Zjednoczonych w Wietnamie.

W rozdziale pierwszym czytelnik ma okazję zapoznać się z ciekawym rysem bibliograficznym jednej z głównych postaci wietnamskiego dramatu - Jeana Baptiste'y Ngo Dinh Diema. Autor prezentuje też sylwetki osób (nie tylko z administracji amerykańskiej), które wspierały wietnamskiego polityka. Badacz skupia swoją uwagę także na pogłębionej analizie filozofii personalistycznej Ngo Dinh Diema. Stanowi to jednak jedynie wstęp do zasadniczych rozważań - wskazania roli, jaką odegrało American Awakening z lat 1950-tych w amerykańskim zaangażowaniu w Wietnamie. Autor zwraca także uwagę na fakt, że zarówno Diem, jak i inni przywódcy proamerykańscy w Azji (Chiang Kai-shek, Syngman Rhee, Ramon Magsaysay) oraz popierający go prominentni Amerykanie (John F. Kennedy, Kardynał Francis Spellman, Gene Gregory, kongresman Clement Zablocki, sędzia William O. Douglas, senator Mike Mansfield) byli katolikami. Przez pracę przewija się wątek wpływu katolicyzmu na amerykańską politykę wobec Wietnamu. Równocześnie Jacobs eksponuje przejawy amerykańskiego etnocentryzmu wymierzonego przeciw buddyzmowi. Autor zwraca uwagę na powszechną ignorancję, zarówno społeczeństwa amerykańskiego, jak i elit władzy dotyczącą Wietnamu.

1 S. Jacobs, America's Miracle Man in Vietnam. Ngo Dinh Diem, Religion, Race, and U.S. Intervention in Southeast Asia, Durham 2004. 
Problematyka drugiego rozdziału koncentruje się wokół America's Third Great Awakening - rozbudzonej religijności Amerykanów w latach pięćdziesiątych, którą łączyć można z trwającą zimną wojną. Autor przedstawia Eisenhowera jako „modlącego się” prezydenta, którego „dziedzictwo jako duchowego przywódcy wykraczało poza retorykę" (s. 68). Prezydentowi przeciwstawia Jacobs Johna Fostera Dullesa (ujęcie bliskie Townsendowi Hoopesowi) - purytanina, „najwyższego kapłana zimnej wojny”, kierującego się w polityce zagranicznej przekonaniami religijnymi jako niepodważalnym imperatywem. Autor stawia znak równości pomiędzy poglądami Dullesa a polityką, którą amerykański sekretarz stanu starał się realizować. Przedstawiając Catholic revival w USA, badacz ukazuje proces zmian zachodzących w katolickiej świadomości - afirmowanie własnej religijności, wzrastająca aktywność organizacji katolickich, antykomunizm czyniący z nich pierwszorzędnych kandydatów do awansu w FBI czy CIA. Jacobs przedstawia także ogromne wpływy kardynała Spellmana oraz wskazuje, iż nawet u Waltera Lippmanna dostrzec można wpływ katolickiej filozofii.

W rozdziale trzecim autor przedstawia sylwetki osób wywierających istotny wpływ na ówczesną opinię publiczną (np. magnat prasowy Henry Luce czy autor „poważnej literatury” James Michener), którzy budowali wizję Azji jako zacofanego kontynentu zamieszkałego przez ludzi, którym obce były wartości Zachodu. Niepiśmienni Azjaci - według Michenera - nie rozumieli demokracji - więc nie mogli w niej aktywnie uczestniczyć, dlatego na tym etapie rozwoju Azji oligarchia stanowiła zdecydowanie lepszą formę rządów, a popieranie azjatyckich satrapów $\mathrm{w}$ ich walce $\mathrm{z}$ komunizmem było $\mathrm{w}$ pełni uzasadnione. $\mathrm{Z}$ tej perspektywy nalegania administracji Trumana, aby Chiang wprowadzał demokrację w trakcie wojny domowej były błędem, którego nie należało powtórzyć w Wietnamie. Przytaczane w pracy przykłady takich poglądów pozwalają wnioskować o charakterystycznym dla ówczesnej Ameryki etnocentryźmie. Nie był to prymitywny darwinizm społeczny o zabarwieniu nazistowskim, a teoria modernizacji, która ustawiała Azjatów w roli dzieci, niezdolnych do uczestniczenia w demokracji bez pomocy „dojrzałego" Zachodu (autor nazywa to racist paternalism). Dopełnieniem rozważań prowadzonych w tej części pracy stają się analizy dotyczące wpływu Hollywood, produkcji telewizyjnych oraz literatury na umacnianie stereotypu (Jacobs wskazuje, iż nawet Quiet American Greene'a nie był wolny od tego typu myślenia).

Dużo miejsca poświęca też autor książce Deliver Us from Evil Thomasa Dooley'a. Po konferencji genewskiej około milion Wietnamczyków, w większości wyznania katolickiego, przeniosło się z północy na południe Wietnamu. Pomagała im marynarka amerykańska, organizując akcję pod kryptonimem Passage to Freedom. Tom Dooley, zapomniany bohater tej akcji, homoseksualista, a zarazem żarliwy katolik, utracjusz wywodzący się z dobrego domu w St. Louis, po niedokończonych studiach medycznych zaciągnął się do marynarki wojen- 
nej, gdzie na pokładzie USS Montague uczestniczył w transporcie uchodźców wietnamskich. Doświadczenia te utrwalił na kartach książki, opisując z detalami tortury, jakim komuniści rzekomo poddawali katolików, a zwłaszcza księży katolickich. Historie te, pełne wstrząsających szczegółów, były - zdaniem Jacobsa - przesadzone. Mimo skłonności do koloryzowania, zasług Dooley'a w trakcie relokacji uchodźców nie można przecenić (np. jego działania zapobiegły wybuchowi epidemii podczas transportu). Relacja Dooley'a stanowi przykład zimnowojennej propagandy, zgodnie z którą Wietnamczycy uciekali z komunistycznego piekła, żeby zakosztować wolności religijnej. Przesiąknięta kompleksem rasistowskim, książka wypromowała zarówno Dooley'a jak i Wietnam w kulturze masowej w USA, a jej autor stał się z dnia na dzień gwiazdą. Ukazując dziecinnych Azjatów wymagających pomocy człowieka Zachodu, eksponując pasywność buddystów skontrastowaną z katolickim zaangażowaniem, wpisywał się w ówczesne oczekiwania społeczne. Dooley według Jacobsa wydatnie pomógł stworzyć fałszywy obraz problemu wietnamskiego oraz ukształtować w masowym odbiorcy amerykańskim poczucie odpowiedzialności za los Wietnamczyków.

Rozdział piąty przynosi szczegółowy obraz misji generała Lawtona Collinsa oraz analizę jego starań zmierzających do usunięcia Diema. Collins jawi się u Jacobsa jako dobry katolik, który, mimo iż potrafił zdiagnozować rzeczywiste słabości wietnamskiego polityka, nie był w stanie odsunąć go od władzy. Według badacza oznaczało to, że „Collinsowi, który był nie tylko słynnym mężem stanu, ale również bliskim przyjacielem prezydenta Eisenhowera, nie udało się przebić przez kognitywną sztywność jego przełożonych. Świadczyło to o sile ideologicznego zaślepienia oraz niemożności zmiany podstawowych poglądów na temat rasy i religii" (s. 174). Collins, który nie był wolny od rasizmu, pozostawał jednak na tyle otwartym człowiekiem, żeby zauważyć, iż Diem nie nadaje się do rządzenia Wietnamem, dlatego też konsekwentnie dążył do mianowania Phan Huy Quata na stanowisko premiera Wietnamu Południowego. Zdaniem Jacobsa porażka Collinsa wynikała także z silnej pozycji „opcji” katolickiej: Mike Mansfield posiadał wówczas efektywne weto w polityce USA wobec Wietnamu i zastąpienie nieefektywnego Diema-katolika sprawniejszym Quatem-buddystą nie było możliwe bez zgody senatora z Montany. Jacobs ukazuje Diema jako polityka niezdolnego do budowy konsensusu, dążącego do konfrontacji, żądnego władzy. Przedstawia szczegółowo kulisy walki pomiędzy Collinsem a Departamentem Stanu i Mansfieldem o kształt polityki amerykańskiej wobec Wietnamu Południowego. Opisuje konferencję paryską z 1955 roku, podczas której rząd Francji de facto przekazał odpowiedzialność za losy Wietnamu w ręce amerykańskiej administracji.

W ostatnim, szóstym rozdziale autor opisuje wizytę Ngo Dinh Diema w Stanach Zjednoczonych oraz rolę, jaką odegrało Amerykańskie Towarzystwo Przyjaciół Wietnamu (American Friends of Vietnam, AFV) w zapewnianiu wiet- 
namskiemu dyktatorowi poparcia Stanów Zjednoczonych. Uwaga badacza koncentruje się na prezentacji okoliczności towarzyszących zakończonej sukcesem wizyty Diema. Autor przypomina o bezprecedensowym przekroczeniu zasady oficjalnych powitań - Eisenhower manifestując poparcie Białego Domu dla wietnamskiego polityka, powitał Diema na płycie lotniska. Jacobs analizuje także pełne poparcia artykuły o Diemie zamieszczane, zarówno w prasie ogólnokrajowej, jak i w specjalistycznych periodykach, takich jak Foreign Affairs czy Pacific Affairs. Jednocześnie zwraca uwagę na fakt, że pochwały kierowane pod adresem Diema w prasie amerykańskiej kontrastowały z pokazywaną przez autora antydemokratyczną rzeczywistością Wietnamu. Jacobs, wbrew Georgowi Herringowi czy Josephowi Morganowi, uważa, że AFV miało istotny wpływ na politykę USA wobec Wietnamu rządzonego przez Ngo Dinh Diema. Szczegółowo opisuje działania takich prominentnych członków towarzystwa jak: Joseph Buttinger, generał John „Iron Mike” O’Daniel, czy Mike Mansfield.

Postawę badacza wobec amerykańskich przywódców ilustrują słowa zakończenia: ,,amerykańscy decydenci sprowadzili również siebie do Wietnamu - swój etnocentryzm i prowincjonalizm, polityczną arogancję i ślepotę kulturową, cały swój bagaż mentalny, który uzbierali od dzieciństwa" (s. 263). Przywołany fragment odsłania jedną z głównych słabości tomu. Jacobs szuka bowiem przyczyn zaangażowania amerykańskiego w Wietnamie na przemian bądź w determinizmie kulturowym epoki bądź w świadomych działaniach jednostek narzucających swoją wolę ogółowi. Zasadnym wydaje się pytanie, jak skuteczne byłyby działania Mike'a Mansfielda, gdyby nie religijność lat pięćdziesiątych. Jeśli aktywność jednostki stanowiłaby tak ważną determinantę, dlaczego Collinsowi nie udało się doprowadzić do usunięcia Diema? Przyjęcie perspektywy proponowanej przez Jacobsa prowadzi do stawiania pytań, na które niezwykle trudno odpowiedzieć. Wskazana słabość pracy wynika $\mathrm{z}$ dwóch problemów. Po pierwsze kwestii metodologicznej: oskarżając historyków dyplomacji o zbyt wąskie traktowanie problemu amerykańskiego zaangażowania w Wietnamie autor popada bowiem w pułapkę zbyt szerokiej analizy problemu. Jacobs próbuje udowodnić istnienie ścisłego związku między publikacjami Luce'a, czy produkcjami Hollywood a decyzjami amerykańskich polityków. Taki dowód jest niemożliwy do przeprowadzenia. Możemy się jedynie domyślać, że jednostki są determinowane w jakimś stopniu przez kulturę społeczeństwa, w którym żyją, trudno zarazem stwierdzić, jak silny jest ów związek, a tym bardziej, w jakim stopniu motywuje konkretne decyzje poszczególnych osób (a już na pewno niemożliwe jest przeprowadzenie takiego dowodu z poziomu metodologii historycznej, którą posługuje się przecież autor). Po drugie kwestii „charakterologicznej” - ulegając swojej ambicji poszukiwań ideologicznych podstaw decyzji polityków, badacz nie stroni od stwierdzeń, których nie powinno się używać w opracowaniach historycznych; pisząc o wyborze Diema na premiera, badacz posuwa się do następującego stwierdzenia: ,rola Dullesa w zapewnieniu wyboru Diema jest trudna 
do ustalenia, lecz z pewnością była ważna i być może decydująca" (s. 54). O ile pierwsza część zdania jest niewątpliwie napisana przez historyka, o tyle jego drugi człon wyszedł już spod pióra historyka idei...

Odrębnym zagadnieniem pozostaje problem (wspólny wielu amerykańskim autorom), zbyt emocjonalnego stosunku do kwestii zaangażowania amerykańskiego w Wietnamie. Widać to wyraźnie w pracy, której ton wydaje się odrobinę zbyt publicystyczny. Książka niewątpliwie zyskałaby na większym wyważeniu tonu wywodów. $\mathrm{W}$ tej zasadniczo dobrze napisanej pracy autor, koncentrując się na tragedii amerykańskiego zaangażowania w Wietnamie, pomija szerszy kontekst tragedii komunistycznego zniewolenia. Krytyka zimnowojennych poczynań Stanów Zjednoczonych bez próby skontrastowania ich z polityką reżymów komunistycznych wypacza obraz epoki. Mimo przywołanych zastrzeżeń praca Jacobsa stanowi ważne uzupełnienie literatury przedmiotu, powinna być jednak czytana przez pryzmat innych książek (np. Diem's Final Failure. Prelude to America's War in Vietnam Philipa Cattona).

Krzysztof Flis

Lublin 